\title{
ANALISIS TEKSTUR ZIRCALOY-4 MENGGUNAKAN METODE WILLIAM-IMHOF-MATTHIES-VINEL (WIMV)
}

\author{
Tri Hardi Priyanto1), Mei Juan $\mathrm{Li}^{2)}$ \\ ${ }^{1}$ Pusat Sains dan Teknologi Bahan Maju - BATAN \\ Kawasan Puspiptek, Serpong, Tangerang Selatan, 15314 \\ e-mail: thardi@batan.go.id \\ ${ }^{2}$ Neutron Scattering Laboratory, China Institute of Atomic Energy (CIAE) - China
}

(Naskah diterima : 3-12-2014, Naskah direvisi: 20-01-2015, Naskah disetujui: 23-01-2015)

\section{ABSTRAK}

ANALISIS TEKSTUR ZIRCALOY-4 MENGGUNAKAN METODE WILLIAM-IMHOF-MATTHIESVINEL (WIMV). Zircaloy-4 sebagai kelongsong bahan bakar nuklir telah banyak diteliti secara makroskopik maupun secara mikroskopik, namun penelitian menggunakan teknik difraksi neutron, terutama karakterisasi orientasi kristalit (tekstur) di Indonesia masih jarang dilakukan. Tujuan penelitian ini adalah untuk menerapkan metode WIMV pada karakterisasi tekstur bahan tersebut. Metode WIMV adalah salah satu metode analisis tekstur bahan yang diperoleh dengan teknik difraksi neutron atau difraksi sinar-X. Dari hasil analisis tersebut diperoleh pole figure 002 dengan indeks tekstur $\left(\mathrm{F}^{2}\right)$ terbesar dibandingkan dengan pole figure yang lain yaitu 100, 101, 102 dan 110. Indeks tekstur $\left(\mathrm{F}^{2}\right)$ pole figure 002 untuk incomplete pole figure, $\mathrm{F}^{2}=4,69$ m.r.d dengan faktor reliabilitas $\mathrm{RP0}=3,28 \%$, dan recalculated pole figure, $\mathrm{F}^{2}=4,42$ m.r.d. dengan $\mathrm{RP} 1=2,97 \%$. Semua pole figure diperoleh faktor reliabilitas dengan pole figure rata-rata $\mathrm{RP0}=6,60 \%$, RP1 $=$ $5,02 \%$, entropy $=-0,5871$, dan indeks tekstur, $F^{2}=2,34$ m.r.d. Hasil analisis bahan Zircaloy- 4 tersebut menyimpulkan bahwa metode WIMV dapat digunakan untuk menentukan arah orientasi tekstur, dimana tekstur yang paling kuat mengarah ke $<001>$ (arah sumbu c) dalam struktur hexagonal.

Kata kunci: Zircaloy-4, WIMV, pole figure, difraksi neutron

\section{ABSTRACT}

TEXTURE ANALYSIS OF ZIRCALOY-4 USING WILLIAM-IMHOF-MATTHIES-VINEL (WIMV) METHOD. Zircaloy-4 as a nuclear fuel cladding has been widely examined macroscopically and microscopically, but research using neutron diffraction technique, especially the characterization of crystallite orientation (texture) in Indonesia is still rare. The purpose of this study is to apply the methods of William-Imhof-Matties-Vinel (WIMV) on the characterization of zircaloy-4 material texture. WIMV is one of data analysis method for textures materials obtained by neutron or $x$-ray diffractions technique. The analysis is obtained that 002 pole figure has the largest texture index $\left(F^{2}\right)$ compared to the others pole figures, that are 100, 101, 102 and 110. Index texture $\left(F^{2}\right)$ of pole figure 002 for incomplete pole figures, $F^{2}=4.69$ m.r.d with a reliability factor $R P 0=3.28 \%$, and recalculated pole figures, $F^{2}=4.42$ m.r.d with $R P 1=2.97 \%$. For all pole figures, it is obtained that a reliability factor of the average $R P 0=6.60 \%, R P 1=5.02 \%$, entropy $=-0.5871$, and texture index $\left(F^{2}\right)=2.34$ m.r.d. Data analysis showed that the WIMV method can be used to determine the direction of the crystallite orientation of the pole figure where the most powerful texture leads to the $<001>$ (c-axis direction) in a hexagonal structure.

Keywords: Zircaloy-4, WIMV, pole figure, neutron diffraction. 


\section{PENDAHULUAN}

Zircaloy-4 merupakan salah satu bahan yang paling populer dalam aplikasi nuklir dari paduan logam berbasis pada zirconium. Karakterisasi struktur komplek pada presipitatnya memegang peranan penting pada sifat-sifat makroskopik bahan seperti kekuatan (strength), keuletan (ductility), kekakuan (stiffness), sensititifitas laju regangan dan ketahanan bahan terhadap korosi. Satu dari karakteristik yang diinginkan saat mendisain paduan zirkonium untuk aplikasi nuklir adalah mempertahankan tampang lintang serapan neutron termal yang rendah dari zirkonium murni. Oleh karena itu, hanya sejumlah relatif kecil dari elemen paduan ditambahkan dan tingkat kotoran sangat ketat, sehingga mereka tidak merugikan penampang lintang untuk neutron termal paduan. Anehnya, pada 1950-an zirkonium dianggap tidak pantas untuk digunakan dalam aplikasi nuklir karena penyerapan neutron termal yang tinggi. Tapi kemudian ditemukan bahwa kehadiran hafnium sebagai pengotor terjadi secara alami bertanggung jawab untuk ini. Sebagai perbandingan tampang lintang neutron termal untuk zirkonium sebesar 0,18 barn dan zircaloy-4 sebesar 0,22 barn. Pengembangan paduan zirkonium terutama telah difokuskan pada pengaruh elemen paduan pada perilaku korosi di dalam air dan uap. Namun hingga saat ini tidak ada konsensus terkait dengan pengaruh elemen yang berbeda. Kebanyakan konflik terjadi karena sejarah proses pembuatan atau korosi lingkungan.

Perkembangan penelitian bahan zircaloy-4 sebagai kelongsong bahan bakar reaktor nuklir telah banyak dilakukan, terutama terkait korosi dan pengaruh hidrida pada zirkonium. Studi dengan TEM yang dilakukan pada daerah yang kaya oksigen dekat interface oksida/ logam mengungkapkan struktur kompleks mempunyai fase yang berbeda pada berbagai tahap korosi. Hidrida juga diamati di wilayah itu, dengan hubungan orientasi yang kuat dengan matriknya ${ }^{[1]}$. Analisis profil garis difraksi neutron dan pengamatan TEM resolusi tinggi (HRTEM) menunjukkan adanya sejumlah dislokasi dalam $\delta$-hydride dengan estimasi kerapatan rata-rata satu tingkat lebih tinggi dari pada matrik $\alpha-Z r^{[2]}$, dan adanya presipitasi hidrida akan menyebabkan korosi pada paduan zirconium ${ }^{[3]}$. Penelitian lain difokuskan pada perilaku Cold Worked Stress Relieved (CWSR), paduan zirconium sebagai tabung kelongsong bahan bakar yang digunakan dalam reaktor air bertekanan (PWR). Tabung tersebut teroksidasi dengan pendingin air selama operasi reaktor. Dengan demikian, lapisan oksida (zirconia) tumbuh ditempat antarmuka air-logam dan hydrogen masuk ke kelongsong. Zirconia bersifat rapuh dan dapat terjadi pecah local jika oksida tumbuh hingga ketebalan yang sangat tinggi. Gradien termal diinduksi di dalam kelongsong memicu thermo-difusi hidrogen menuju daerah terdingin, di mana oksida itu pecah. Apabila kelarutan hidrogen dalam zirconium melebihi batas, atom hydrogen menyebar dan kemudian mengendap dalam bentuk hidrida zirconium di tempat dingin tersebut, membentuk daerah yang sangat hydrid yang disebut gelembung hidridaa ${ }^{[4]}$. Selain itu juga telah dilakukan penelitian untuk meningkatkan penguatan resistansi terhadap korosi dan kekuatan yang lebih baikpada bahan zircaloy-4 dengan modifikasi permukaan menggunakan sinar laser ${ }^{[5]}$. Untuk melihat pertumbuhan pengaruh hidrogen pada zircaloy-4 juga telah dilakukan eksperimen dilatometrik dalam rangka mengetahui perilaku dilatometrik dari hidrida zirkonium[6].

Penelitian tekstur pada bahan Zircaloy-4 menggunakan metode difraksi neutron juga telah dilakukan di Indonesia. Penelitian tekstur dengan teknik difraksi neutron melengkapi pengukuran tekstur secara lokal menggunakan SEM atau difraksi sinar-X. Pengukuran tekstur dibagi menjadi dua kelompok yaitu pengukuran 
makrotekstur menggunakan metode difraksi neutron dan metode difraksi sinar- $\mathrm{X}$, dan pengukuran mikrotekstur dengan menggunakan metode difraksi Kikuchi, teknik berdasarkan Scanning Electron Microscope (SEM) yaitu teknik micro-kossel, Electron Channelling Diffraction, Electron Backscatter Diffraction (EBSD), dan teknik berdasarkan Transmission Electron Microscopy (TEM) yang terdiri dari High-Resolution Electron Microscopy dan Selected Area Diffraction, pola Kikuchi, micro-difraction dan Convergent Beam Electron Diffraction.

Pengukuran makrotekstur dengan difraksi neutron dan difraksi sinar- $X$ mempunyai perbedaan ditinjau dari sifat interaksi materi dengan berkas neutron dan berkas sinar-X. Neutron memiliki daya tembus yang jauh ke dalam bahan karena neutron tidak bermuatan, neutron memiliki spin magnetik sehingga dapat terjadi interaksi magnetik pada bahan yang dikarakterisasi. Sedangkan interaksi bahan dengan sinar- $X$ hanya pada permukaan saja dan berupa interaksi elektron. Pengukuran tekstur bulk dengan difraksi neutron diperlukan untuk validasi hasil pemodelan, memahami perkembangan tekstur selama rute pengolahan bahan atau cuplikan geologi dengan butir (grain) yang besar. Kelebihan difraksi neutron dibandingkan difraksi sinar- $X$ dapat ditinjau dari persiapan cuplikan yakni pada metode sinar- $X$ atau elektron untuk pengukuran tekstur secara kuantitatif memerlukan persiapan cuplikan secara hatihati dengan tujuan untuk meminimalkan efek permukaan, koreksi penyerapan yang pada umumnya rumit untuk cuplikan dengan butir yang besar. Ketiga hal tersebut yakni efek permukaan, koreksi serapan dan ukuran butir dapat dihindari ketika pengukuran tekstur bulk dilakukan menggunakan difraksi neutron[7]. Juga sifat atenuasi yang rendah oleh sebagian besar bahan menyebabkan neutron menembus ke dalam bahan yang palingjauh dibandingkan dengan sinar- $X$ sehingga membuat penyiapan permukaan cuplikan dan efek penyerapan bahan diabaikan.

Dalam hal pengukuran tekstur faktor tekstur kristalografi memegang peranan penting pada bahan, misalnya pada kelongsong bahan bakar nuklir. Parameter tekstur kristalografi merupakan faktor yang sangat penting untuk paduan zirconium karena telah diketahui dengan baik bahwa sifat fisik seperti halnya creep, orientasi hidrida juga perilaku pertumbuhan akibat iradiasi dipengaruhi oleh preferred grain orientation dari paduan berbasis zirconium. Karena itu faktor tekstur kristalografi untuk paduan berbasis zirconium harus dipertimbangkan dan menjadi bagian penting pada penerapannya untuk komponen nuklir[8]. Metode analisis tekstur telah berkembang dengan beberapa metode, salah satunya adalah metode Wiliam-ImhofMatthies-Vinel (WIMV) ${ }^{[9,10]}$ yang digunakan pada penelitian ini.

Tujuan dari penelitian ini adalah melakukan analisis tekstur melalui pole figure dan indeks tekstur untuk mendapatkan fungsi distribusi orientasi (ODF). Bahan plat warmrolled zircaloy-4 dikarakterisasi dengan teknik difraksi neutron dan data pole figure dianalisis dengan metode WIMV.

\section{a. Notasi simbol dalam teori ${ }^{[0]}$}

Analisis tekstur secara kuantitatif mempunyai banyak simbol yang digunakan dalam teori terkait dengan pole figure, fungsi distribusi orientasi (ODF) dan lain-lain. Untuk itu simbol-simbol yang terkait disajikan pada Tabel 1.

Tabel 1. Simbol yang digunakan

\begin{tabular}{|ll|}
\hline$y$ & $:$ Arah cuplikan \\
$h_{i}$ & : Arah kristal \\
$f(g)$ & : Orientation distribution \\
& function (ODF) \\
$f^{M}(g)$ & $:$ Method-dependentODF yang \\
& diturunkan dari pole figure \\
$\tilde{f}(g)$ & : ODF tereduksi konsisten \\
& dengan pole figure \\
\hline
\end{tabular}




\begin{tabular}{|c|c|}
\hline & $\begin{array}{l}\text { (diekspresikan oleh koefisien } \\
\text { harmonik genap) }\end{array}$ \\
\hline$P_{h_{i}}(y)$ & : Pole figure dari arah kristal $h_{i}$ \\
\hline $\mathcal{P}_{h_{i}}(y)$ & $\begin{array}{l}\text { : Pole figure ideal, } \\
\text { membedakan arah non- } \\
\text { ekivalen positip dan negatip } \\
h_{i}\end{array}$ \\
\hline$\tilde{P}_{h}(y)$ & $\begin{array}{l}\text { : Pengukuran pole figure } \\
\text { centrosymmetric (reduksi) }\end{array}$ \\
\hline$\tilde{P}_{h_{i}}^{M}(y)$ & $\begin{array}{l}\text { : Pole figure tereduksi dihitung } \\
\text { ulang (recalculated) dari } \\
f^{M}(g)\end{array}$ \\
\hline$P\left(h_{i}, y\right)$ & $\begin{array}{l}\text { : Simbol yang umum untuk } \\
\text { variasi jenis pole figure }\end{array}$ \\
\hline
\end{tabular}

b. Kriteria kesalahan dalam analisis tekstu ${ }^{[9]}$

Dalam analisis tekstur, eksperimental pole figure adalah informasi utama yang dimiliki. Perbandingan $\tilde{P}_{h_{i}}\left(y_{j}\right)$ dengan $\tilde{P}_{h_{i}}^{M}\left(y_{i}\right)=\tilde{P}\left(h_{i}, y_{j}, g\right) f^{M}(g)$ yang dihitung ulang (recalculated) dari reproduksi ODF dapat memberikan kriteria numerik untuk kualitas solusi.

Perbedaan pole figure $\Delta \tilde{P}_{h}\left(y_{i}\right)$

$\Delta \tilde{P}_{h}\left(y_{i}\right) \equiv \tilde{P}_{h_{i}}\left(y_{j}\right)-\tilde{P}_{h_{i}}^{M}\left(y_{i}\right), j=1,2, ., J$,

adalah kemungkinan untuk mendemonstrasikan secara grafik deviasi suatu area secara sistematik. Penilaian secara keseluruhan dari kualitas dapat diekspresikan dengan kesalahan rata-rata $R_{w}$ dengan bobot area $S_{j}$ dari sel pole figure $c_{j}$ disekitar $y_{j}$ yang dinyatakan sebagai:

$S_{j}=\int_{c_{j}} \sin \theta d \theta d \varphi$,

dan

$\left.R_{w}=100 \%\left(\sum_{j=1}^{J} S_{j} \mid \Delta \tilde{P}_{h}\left(y_{i}\right)\right)\right) /\left(\sum_{j=1}^{J} S_{j} \tilde{P}_{h_{i}}\left(y_{j}\right)\right)$

Kemungkinan lain, akar dari kesalahan dapat digunakan untuk menyatakan deviasi yang besar, tetapi ketika kesalahan rata-rata dapat mengindikasikan permasalahan data atau metode untuk masalah fisika secara umum, mungkin hal ini tidak cocok untuk tekstur.
Disebabkan oleh normalisasi ODF, pole figure dan karena karakter probabilitas, angka 1 menunjukkan distribusi orientasi yang acak memainkan peran serupa dalam analisis tekstur dengan angka nol untuk quantiities fisika umum yang merupakan batas antara negatif dan positif.Untuk kasus bahan tidak bertekstur (textureless), berlaku $f(g)=1, \tilde{P}_{h_{i}}(y)=1$, dan nilai $f(g)>$ 1, $\left[\tilde{P}_{h_{i}}(y)>1\right]$ hanya dapat timbul jika titik-titk dengan $f(g)<1,\left[\tilde{P}_{h_{i}}(y)<1\right]$ ada secara simultan, masing-masing dalam ruang $G$ dan Y. Dengan kata lain dua kondisi ODF, yaitu $1<f(g)<\infty$ dan $0 \leq f(g) \leq 1$, direproduksi dengan akurasi yang sama. Dalam kaitan ini latar belakang isotropik yang disebut "phon", "murmur", "noise" atau "ghost" memainkan peranan penting, yaitu:

$F \equiv \min \{f(g)\}, 0 \leq F \leq 1$

Dapat juga diinterpretasikan dalam bentuk berapa banyak kristalit yang terorientasi ke arah tertentu (textured) yakni $[100 \%(1-F)]$ dan seberapa banyak yang terorientasi acak $(100 \% F)$

Menganalisis karakteristik kesalahan pada pers (3) dari sudut pandang ini dapat segera terlihat bahwa ekspresi yang sesuai dalam membedakan area dengan nilai $\widetilde{P}_{h_{i}}(y)$ yang kecil dalam eksperimen difraksi tersebut kemungkinan besar akan mengakibatkan kesalahan absolut yang besar. Hal ini dapat diatasi dengan mempertimbangkan deviasi relatif seperti

$r_{i, j}=\frac{\left|\tilde{P}_{h_{i}}(y)-\tilde{P}^{M}{ }_{h_{i}}(y)\right|}{\tilde{P}_{h_{i}}(y)}$

dengan memperkenalkan fungsi seleksi:

$$
\begin{gathered}
\theta(\varepsilon, x)=0 \text { untuk } x \leq \varepsilon \\
=1 \text { untuk } x>\varepsilon
\end{gathered}
$$

nilai RP atau faktor reliabilitas pole figure dinyatakan sebagai

$R P_{i, j}(\varepsilon) \equiv R P_{i j}=100 \% \theta\left[\varepsilon, \widetilde{P}_{h_{i}}(y)\right] r_{i, j}$

"Local error" dengan bentuk spesial sering dinyatakan sebagai $R P 0_{i j}=R P_{i, j}(0) R P 1_{i j}=$ $R P_{i, j}$ (1)yang berkaitan dengan kuantitas 
rata-rata $R P_{i}, R P 0_{i}, R P 1_{i}, R P, R P 0$, dan $R P 1$ dinyatakan sebagai

$$
\begin{aligned}
& R P_{i}=\sum_{j=1}^{J} R P_{i, j} / \sum_{j=1}^{J} \theta\left(\varepsilon, \tilde{P}_{h_{i}}(y)\right) \\
& R P=\sum_{i=1}^{I} R P_{i} / I
\end{aligned}
$$

nilai $R P$ jauh lebih sensitif dari $R_{w}$ dan dapat mencapai nilai yang besar, misalnya diperoleh data ekperimen pole figure dengan statistik yang buruk, tekstur yang tajam dengan resolusi buruk, series-termination effect dan sel yang besar dalam ruang $\mathrm{G}$.

\section{c. Karakteristik koreksi ghost, murmur, phon atau noise ${ }^{0}$}

Kondisi $f^{M}(g) \geq 0$ menyebabkan masalah non linier yang hanya dapat dipecahkan dengan cara iteratif. Estimasi awal dari solusi ODF, algoritma iteratif dan syarat tambahan yang diformulasikan secara ekasplisit semuanya menentukan hasil $f^{M}(g)$. Sebagai contoh satu parameter yang mengkarakterisasi $f^{M}(g)$, adalah indeks tekstur yang menunjukkan ketajaman ODF yang dinyatakan sebagai

$f^{2} \equiv \int_{G} \frac{f^{2}(g) d g}{8 \pi^{2}} \approx \sum_{n=1}^{n_{G}} f^{2} V_{n} / 8 \pi^{2}$

dengan $V_{n}$ adalah volume sel ruang-G

\section{d. Metode WIMV (William-Imhof- Matthies-Vinel) ${ }^{0}$}

Metode analisis tekstur secara kuantitatif dibagi menjadi tiga metode reproduksi yaitu metode harmonik, metode vektor dan metode WIMV. Pada awalnya metode reproduksi dikembangkan oleh William pada tahun 1968 dan Imhof pada tahun 1982 melakukan analisis detail dari "ghost" atau "latar belakang isotropik". Matthies dan Vinel (1982) kemudian mengembangkan satu metode reproduksi iteratif dengan kondisi koreksi "ghost" yang disuplai untuk nilai $R P$ minimum $f_{g}^{M} \geq 0$ dengan indeks tekstur maksimum (sedikit, tapi mempunyai puncak-puncak yang tajam). Elemen dasar dari metode adalah fungsi perkalian (product function) dari

$\prod_{i=1}^{l} \prod_{m i=1}^{M i} \tilde{P}_{h}\left(g^{-1}, h_{m}\right), \quad h_{m} \in \tilde{g}_{h_{j}} . h_{i}, \quad \tilde{g}_{b_{i}} \in \widetilde{g}_{B}$
Dimana $f^{M}(g)$ selalu $\geq 0$ dan ia menghasilkan solusi eksak untuk setiap "zero fibre" yang diasosiasikan dengan $\tilde{P}_{h}\left(y_{m}^{0}\right)=0$, dengan kata lain $f\left(G_{F_{m}}\right)=0$. Kondisi ini ditambah dengan mensyaratkan "phon"maksimum $\quad F \equiv \min \left\{f^{M}(g)\right\} \rightarrow \max$ untuk sebuah $R P$ minimum.

\section{METODOLOGI}

\section{a. Persiapan cuplikan}

Dua buah potongan plat warm-rolled ziralloy-4 berukuran $12 \mathrm{~mm}$ sepanjang arah tranvesal (TD) x $12 \mathrm{~mm}$ sepanjang arah pengerolan (RD) dengan ketebalan $6 \mathrm{~mm}$ disatukan, sehingga membentuk kubus dengan ukuran $12 \mathrm{~mm} \times 12 \mathrm{~mm} \times 12 \mathrm{~mm}$. Cuplikan ini selanjutnya digunakan untuk mengambil data tekstur. Cuplikan ini diproduksi oleh Wah Chang, Amerika Serikat (ASTM B352, Grade R60804). Bahan semacam ini telah digunakan untuk membuat bejana reflektor reaktor riset OPAL, ANSTO Australia[12].

\section{b. Metode ekperimen}

Eksperimen difraksi neutron dilakukan menggunakan difraktometer tekstur DN2 di Laboratorium Hamburan Neutron, Pusat Sains dan Teknologi Bahan Maju, BATAN. Difraktometer tekstur DN2 menggunakan panjang gelombang 1,2799 ^̊ yang dihasilkan dari monokromator Si (311).

Untuk mengurangi berkas neutron terhambur, antara monokromator dan cuplikan dipasang flight tube dengan ukuran $30 \mathrm{~mm}(\mathrm{~L}) \times 90 \mathrm{~mm}(\mathrm{H})$. Celah berkas (beam slit) maksimum berukuran $30 \mathrm{~mm} \times 30 \mathrm{~mm}$. Detektor monitor dan detektor utama menggunakan BF3. Cuplikan berbentuk kubus dengan ukuran $12 \mathrm{~mm} \times 12 \mathrm{~mm} \times 12$ $\mathrm{mm}$ di set di meja cuplikan. Celah berkas (beam slit) neutron datang ke cuplikan dan neutron terdifraksi dari cuplikan di set pada ukuran maksimum (30 mm × $30 \mathrm{~mm}$ ).

Mula-mula semua parameter sudut difraksi $(\theta, 2 \theta)$, rotasi $\phi$ dan tilt $\chi$ cuplikan di set pada sudut nol derajat. Selanjutnya dipilih 
input parameter elemen (unsur) atau paduan (alloy) untuk jenis cuplikan yang sesuai dengan cuplikan yang digunakan dalam eksperimen.

Dalam eksperimen ini dipilih $\mathrm{Zr}$ sebagai elemen utama. Sudut difraksi teoritis dihitung berdasarkan parameter kisi dan panjang gelombang sesuai dengan rumus hukum Bragg $\lambda=2 d \sin \theta$. Pada eksperimen dengan struktur hexagonal dipilih minimal empat bidang Bragg untuk memperoleh data pole figure. Setelah itu eksperimen pole figure dilakukan dengan menggunakan mode tekstur autoscan. Mode tekstur autoscan adalah mode pengambilan data difraksi dengan mode $(\theta, 2 \theta)$ dengan step $0,1^{\circ}$ dan dilanjutkan dengan pengambilan data pole figure dimana $(\theta, 2 \theta)$ diset pada sudut Bragg tertentu sesuai dengan puncak Bragg yang dipilih dengan melakukan scan rotasi dan tilting $(\phi, \chi)$, dengan masing-masing stepscan sebesar $5^{\circ}$.

Pengambilan data cacahan neutron dilakukan menggunakan mode preset count. Incomplete pole figure diperoleh sampai sudut $\alpha=75^{\circ}$ dimana $\alpha=90^{\circ}-\chi$. Dalam eksperimen ini digunakan penulisan index (hkl) dengan indeks Miller (hkl).

\section{HASIL DAN PEMBAHASAN}

\section{a. Pola difraksi neutron}

Hasil penelitian sebelumnya tentang penentuan basal-pole pada Zircaloy-4 diperoleh parameter kisi hasil refinement dengan menggunakan program MAUD (Materials Analysis Using Diffraction) yaitu a $=3,2288 \AA$ and $c=5,1554 \AA^{[13]}$. Parameter kisi ini selanjutnya digunakan sebagai salah satu parameter masukan untuk eksperimen tekstur. Untuk keperluan analisis tekstur tersebut digunakan pola difraksi yang diperoleh dengan difraktometer tekstur DN2 dalam mode $d$-spacing seperti ditunjukkan pada Gambar 1a. Angka 1 s/d 5 menunjukkan puncak Bragg untuk Zirconium pada bidang (100), (002), (101), (102), dan (110). Gambar 1b menunjukkan perbandingan spektrum untuk data eksperimen dan data hasil fitting terhadap jarak antar bidang (d-spacing).

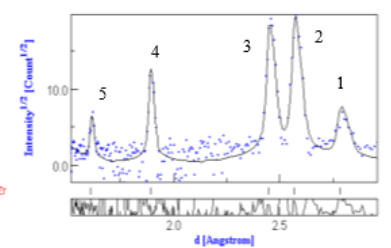

a)

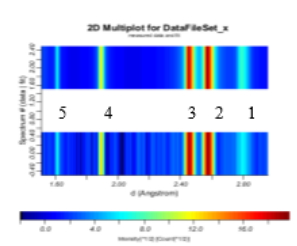

b)
Gambar 1 a) Pola difraksi Zircaloy-4 dinyatakan dalam jarak antar bidang bragg (hkl)

b) Perbandingan spektrum data eksperimen dengan data hasil fitting terhadap jarak antar bidang (dspacing). Perbedaan warna menunjukkan akar intensitas $(\sqrt{I})$ yang sebanding dengan faktor struktur $(F)$.

\section{b. Analisis pole figure}

Pole figure adalah proyeksi ODF sepanjang garis dalam ruang orientasi yang berhubungan dengan rotasi $2 \pi$ terhadap vektor hamburan. Eksperimen dengan sebuah pole figure dapat dilakukan hanya untuk menunjukkan orientasi kristal yang diukur secara individual, bukan ODF. Permasalahan dalam analisis tekstur adalah menentukan ODF tiga-dimensi dari satu set eksperimental pole figure dua-dimensi, dengan kata lain untuk mendapatkan ODF dari proyeksinya. Sebuah complete pole figure dengan grid $5^{\circ}$ diperoleh data pengukuran $19 \times 72=1368$ titik, sehingga untuk $n$-pole figurediperoleh datapengukuran sebanyak $19 \times 72 \times n$ titik. Dalam eksperimen pole figure jumlah pole figure yang diperlukan untuk menentukan arah orientasi kristalit tergantung pada struktur kristalnya, untuk struktur hexagonal diperlukan minimal empat pole figure.

Eksperimen ini menggunakan lima buah incomplete pole figure dengan $\alpha=75^{\circ}$ dimana $\alpha=90^{\circ}-\chi, \chi$ adalah sudut tilt, sehingga untuk sebuah incomplete pole 
figure diperoleh data pengukuran $16 \times 72=$ 1152 buah.

Dalam eksperimen ini diambil lima buah pole figure, masing-masing untuk puncak Bragg (100), (002), (101),(102), dan (110) yang dinyatakan dalam notasi index Miller atau puncak

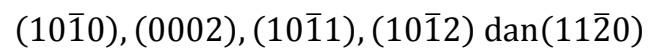
dalam notasi index Miller-Bravais. Meskipun dinyatakan dengan secara berbeda, keduanya mempunyai $d$-spacing yang sama. Analisis pole figure untuk incomplete pole figure dan recalculated norm pole figure dengan metode WIMV dilakukan menggunakan program Beartex.

Hasil analisis dengan metode WIMV memperlihatkan lima buah incomplete pole figure ditunjukkan yang pada Gambar 2. Data untuklima pole figure tersebut telah dikoreksi dengan cacahan latar untuk setiap cacahan di sekitar masing-masing puncak Bragg. Analisis menggunakan metode WIMV diperoleh nilai fungsi distribusi orientasi minimum dan maksimum, masing-masing bernilai 0 dan 4.69 m.r.d (multiple of a random distribution). Hasil proses recalculated normpole figure seperti ditunjukkan pada Gambar 3. Lima experimental pole figured an recalculated norm keduanya di plot dari 0,04 sampai 4,44 m.r.d. Hasil refinement pole figure dengan perangkat lunak Beartex ditunjukkan pada Tabel 1.

Tabel 1 memperlihatkan nilai $O D F$ minimum dan maksimum untuk setiap pole figure. Dari kelima pole figure tersebut dapat ditunjukkan bahwa pole figure 002 mempunyai indeks tektur 0,04 m.r.d dan maksimum 4,69 m.r.d. Hal ini menunjukkan bahwa arah orientasi kristalit sebagian besar mengarah pada arah sumbu c dalam struktur kristal hexagonal, dan merupakan arah orientasi terkuat dengan indeks reliabilitas $R P O=3,28 \%$ dan $R P 1=2.97 \%$. Secara keseluruhan, nilai rata-rata hasil refinement dengan metode WIMV diperoleh ODF minimum dengan indeks tekstur $=0,02$ m.r.d dan ODF maksimum dengan indeks tekstur $=6.84$ m.r.d. Tekstur indeks $\left(F^{2}\right)$ rata-rata $=$ 2,3363 m.r.d. RPO $=6.6045 \%$ dan $R P 1=5.0225 \%$, entropy $=-0,5871$

Tabel 1. Hasil refinement pole figure dengan metode WIMV

\begin{tabular}{|c|c|c|c|c|c|c|c|c|c|}
\hline \multirow{2}{*}{$\mathrm{h}$} & \multirow{2}{*}{$\mathrm{k}$} & \multirow{2}{*}{ I } & $R P 0$ & $R P 1$ & $F^{2} \min$ & $F^{2} \max$ & \multirow{2}{*}{$\begin{array}{l}\alpha \min \\
(\mathrm{deg})\end{array}$} & \multirow{2}{*}{$\begin{array}{c}\alpha \max \\
\text { (deg) }\end{array}$} & \multirow{2}{*}{$\begin{array}{c}\text { Pole } \\
\text { figures }\end{array}$} \\
\hline & & & \multicolumn{2}{|c|}{$(\%)$} & \multicolumn{2}{|c|}{ (m.r.d) } & & & \\
\hline 1 & 0 & 0 & 8,49 & 5,37 & 0,23 & 2,48 & 0,0 & 75,0 & Exp.norm \\
\hline 1 & 0 & 0 & 8,49 & 5,37 & 0,32 & 3,14 & 0,0 & 75,0 & Recal.norm \\
\hline 0 & 0 & 2 & 3,28 & 2,97 & 0,04 & 4,69 & 0,0 & 75,0 & Exp.norm \\
\hline 0 & 0 & 2 & 3,28 & 2,97 & 0,04 & 4,42 & 0,0 & 75,0 & Recal.norm \\
\hline 1 & 0 & 1. & 5,32 & 4,65 & 0,55 & 1,53 & 0,0 & 75,0 & Exp norm \\
\hline 1 & 0 & 1. & 5,32 & 4,65 & 0,59 & 1,51 & 0,0 & 75,0 & Recal.norm \\
\hline 1 & 0 & 2 & 7,09 & 6,91 & 0,17 & 1,91 & 0,0 & 75,0 & Exp norm \\
\hline 1 & 0 & 2 & 7,09 & 6,91 & 0,14 & 1,69 & 0,0 & 75,0 & Recal.norm \\
\hline 1 & 1 & 0 & 8,84 & 5,22 & 0,26 & 2,34 & 0,0 & 75,0 & Exp norm \\
\hline 1 & 1 & 0 & 8,84 & 5,22 & 0,31 & 2,90 & 0,0 & 75,0 & Recal.norm \\
\hline
\end{tabular}




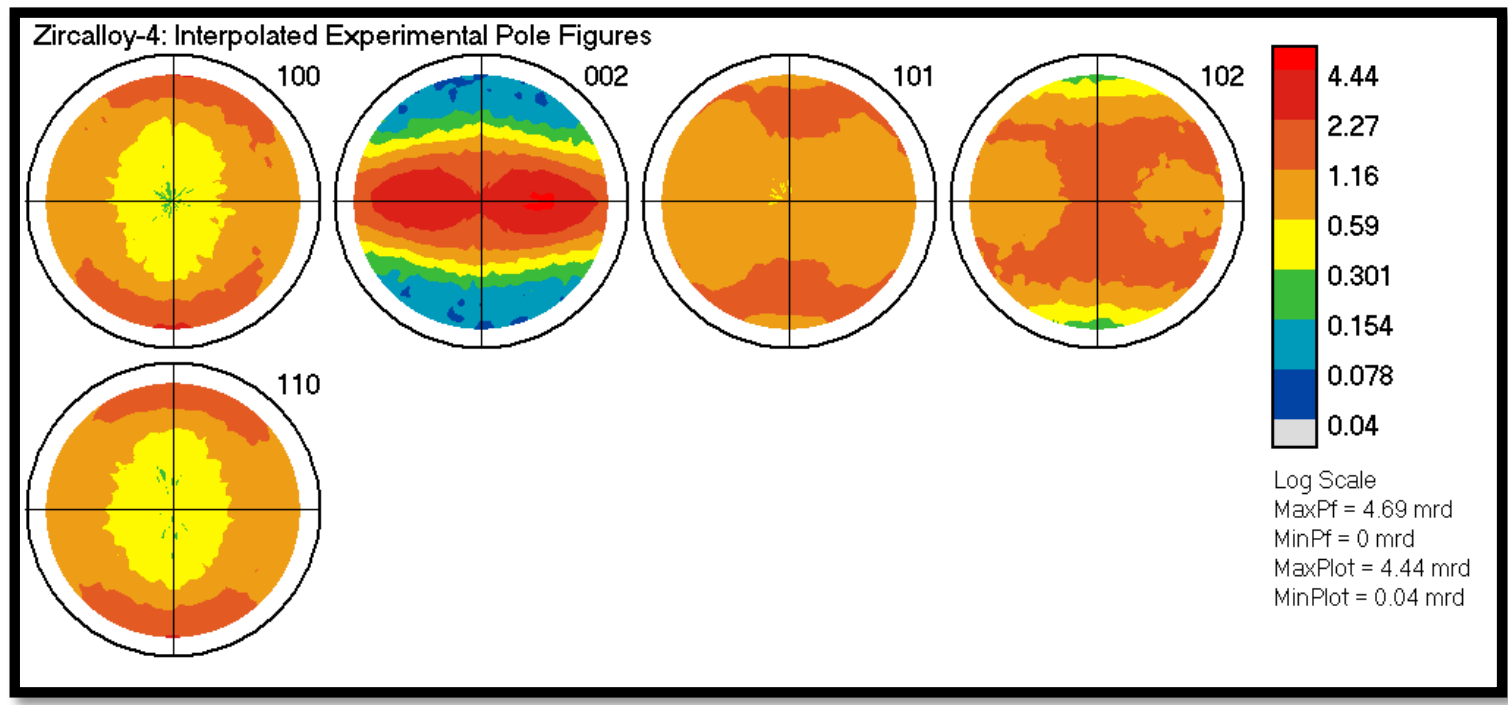

Gambar 2. Incomplete pole figures zircaloy-4 untuk pole figure (100), (002), (101), (102) dan (110)

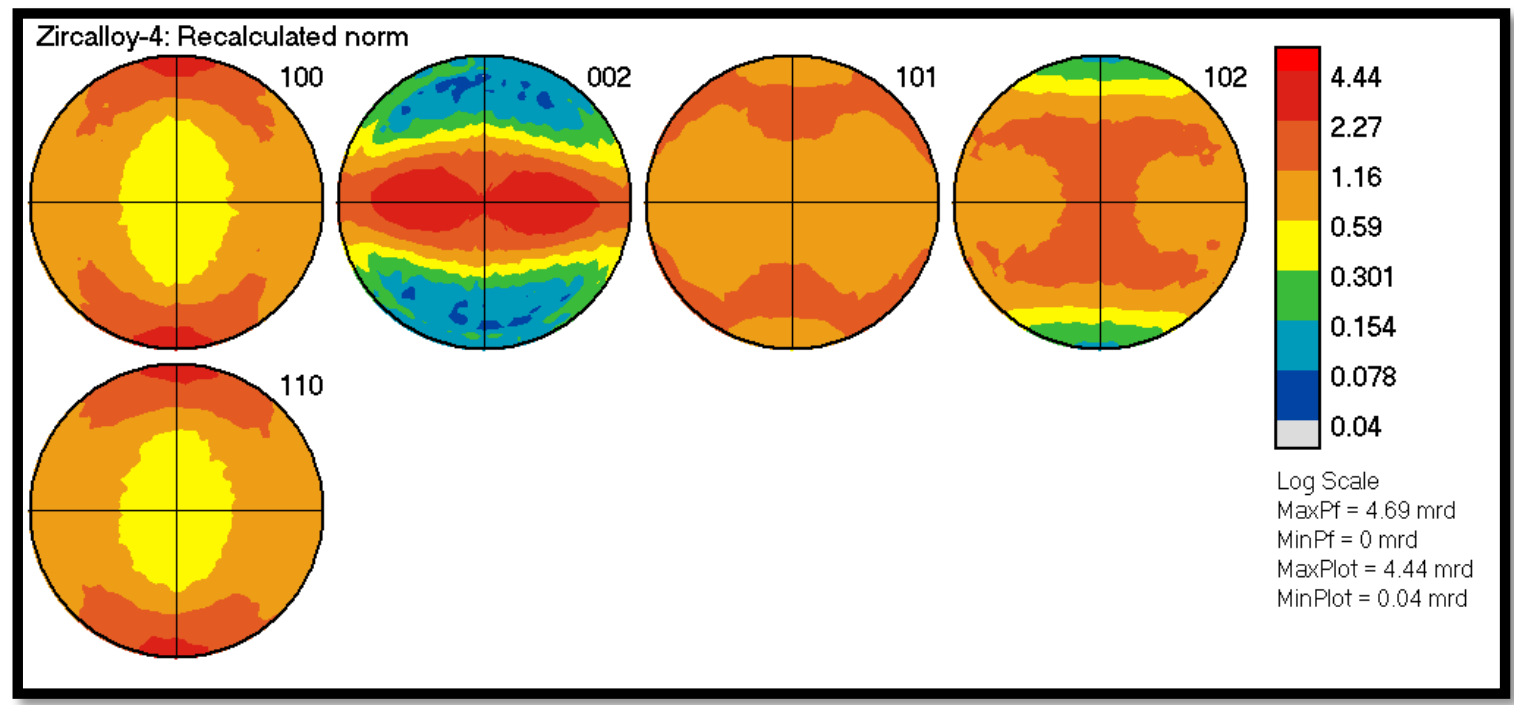

Gambar 3. Recalculated normpole figures zircaloy-4 untuk pole figure (100), (002), (101), (102) dan (110)

Hasil eksperimen pole figure menunjukkan bahwa metode WIMV dapat digunakan untuk menganalisis data pole figure untuk Zircaloy-4, dan metode tersebut dapat menunjukkan letak pole yang mengindikasikan orientasi kristalit (tekstur) pada bahan. Untuk Zircaloy-4 yang digunakan sebagai kelongsong bahan bakar nuklir, adanya tekstur sangat berpengaruh pada sifat kekuatan bahan dan juga laju korosi dan pembentukan hidrida pada Zircaloy-4[2].

\section{SIMPULAN}

Pole figure dengan lima puncak Bragg pada bidang (100), (002), (101), (102), dan (110) menunjukkan bahwa arah orientasi kristalit (tekstur) yang paling kuat mengarah ke arah sumbu c $($ arah $<001>)$ dalam struktur hexagonal.

Hasil analisis dengan metode WIMV pada cuplikan zircaloy-4 mendapatkan hasil yang cukup baik dan dapat dipakai untukanalisis tekstur pada bahan logam atau paduan logam lainnya. 


\section{UCAPAN TERIMA KASIH}

Penulis mengucapkan terima kasih terutama kepada Bharoto, M.Eng yang telah membantu mengembangkan sistem perangkat lunak untuk sistem kontrol dan akusisi data difraktometer tekstur DN2. Ahmad Ramadhani, AMd yang turut mengembangkan sistem elektronik dan mekanik untuk sistem kontrol difraktometer tekstur DN2. Penulis juga mengucapkan terima kasih kepada para teknisi yang terlibat dalam Sistem Dukung Laboratorium Hamburan Neutron, Pusat Sains dan Teknologi Bahan Maju (PSTBM), BATAN.

\section{DAFTAR PUSTAKA}

[1] Benoit de Gabory, Arthur T. Motta, Ke Wang, (2015), Transmission Electron Microscopy Characterization of Zircaloy4 and ZIRLO $^{\text {TM }}$ Oxide Layers, Journal of Nuclear Materials 456, 272-280.

[2] Zhiyang Wang, Ulf Garbe, Huijun Li, Yanbo Wang, Andrew J. Studer, Guangai Sun, Robert P. Harrison, Xiaozhou Liao, M.A. Vicente Alvarez, J.R. Santisteban and Charlie Kong, (2014), Zircaloy-4 Materials By Electron Microscopy And Neutron Diffraction, J. Appl. Cryst, 47, 303-315.

[3] Allen, T.R., R.J.M. Konings, A. T. Motta and J. M. K Rudy, (2012), Editor-in-chief, Corrosion of Zirconium Alloys, Comprehensive Nuclear Materials, Oxford, Elsevier, 49-68.

[4] Vincent Macdonald, David Le Boulch, Arthur Hellouin de Menibus, Jacques Besson, Quentin Auzoux, Jérôme Crépin, Thomas Le Jolu, (2014), Fracture of Zircaloy-4 Fuel Cladding Tubes With Hydride Blisters. Procedia Materials Science 3, 233-238.

[5] Hyun-Gill Kim, II-Hyun Kim, Yang-II Jung, Domg-Jun Park, Jeong-Yong Park, and Yang-Hyun Koo, (2014), Microstructure And Mechanical Strength of Surface ODS Treated Zircaloy-4
Sheet Using Laser Beam Scanning. Nuclear Engineering and Technology, Vol. 46 No. 4.

[6] Arthur Hellouin de Menibus, Thomas Guilbert, Quentin Auzoux, Caroline Toffolon, Jean-Christophe Brachet, Jean-Luc Bechade, (2013), Hydrogen Contribution To The Thermal Expansion Of Hydrided Zircaloy-4 Cladding Tubes. Journal of Nuclear Materials 440, 169177.

[7] Olaf Engler, Valerie Randle, (2010), Introduction to Texture Analysis, Macrotexture, Micotexture and Orientation Mapping. CRC Press, 75201.

[8] Yoon-Soo Lim, Hyun-Gil Kim and YongHwan Jeong, (2008), Experimental Evaluation of Rolling Reduction and Heat-Treatment Effects on the Texture and Creep Behavior of a Zircaloy-4. Materials Transactions, Vol 49, No 8, 1922-1925.

[9] S. Matthies, H.-R. Wenk, G.W. Vinel, (1988), Some Basic Concepts of Texture Analysis and Comparison of three Methods to Calculate Orientation Distribution from pole figure. J. Appl. Cryst. 21, 285-304.

[10] H.-R. Wenk, L. Lutterotti, S. Vogel, (2003), Texture Analyisis with the new HIPPO TOF diffractometer. Nuclear Instruments and Methods in Physics Research A 515, 575-588.

[11] D.G. Carr, M.I. Ripley, D.W. Brown, S.C. Vogel and T.M. Holden, (2006), Residual Stress Measurements On A Stress Relieved Zircaloy-4 Weld By Neutron Diffraction. Journal of Nuclear Materials 359, 202-207.

[12] Javier Santisteban, (2012), Proposal For A Round Robin On Neutron Diffraction Determinationof Texture Of Zr-Based Alloys Coordinated By IAEA Within The CRP Development, Characterization And Testing Of Materials Of Relevance To Nuclear Energy Sector Using Neutron Beams. Centro Atómico 
Bariloche, Comisión Nacional de Energía Atómica, Argentina.

[13] Tri Hardi Priyanto, Bharoto, Ahmad Ramadhani, (2014), Determination Of Basal-Pole On Round Robin Zircaloy-4 Using Pole Figure And Stereographic
Projection Method. Diseminarkan dalam International Conference On Materials Science And Technology (ICMST). 